\title{
Characterization and Utilization of Eziulo Clay as an Extender in Emulsion Paint Formulations
}

\author{
Isaac 0. Igwe*, Gift Osuoha, Chinedu Nwapa \\ Department of Polymer and Textile Engineering, Federal University of Technology, Owerri, Nigeria \\ Email: *zik3gh@gmail.com, giftosuoha@yahoo.com, edunwapa@gmail.com
}

How to cite this paper: Igwe, I.O., Osuoha, G. and Nwapa, C. (2017) Characterization and Utilization of Eziulo Clay as an Extender in Emulsion Paint Formulations. Journal of Minerals and Materials Characterization and Engineering, 5, 174-184. https://doi.org/10.4236/jmmce.2017.54015

Received: March 30, 2017

Accepted: June 30, 2017

Published: July 3, 2017

Copyright $\odot 2017$ by authors and Scientific Research Publishing Inc. This work is licensed under the Creative Commons Attribution International License (CC BY 4.0).

http://creativecommons.org/licenses/by/4.0/

\begin{abstract}
A series of emulsion paint samples were prepared using Eziulo clay as an extender, commercial whiting, and titanium dioxide $\left(\mathrm{TiO}_{2}\right)$. The clay that was calcined at $850^{\circ} \mathrm{C}$ and sieved to three particle sizes $(0.075,0.100$ and 0.150 $\mathrm{mm}$ ) was incorporated into emulsion paints at varying amounts ranging from $5 \%-32 \%$ of the total extender and pigment in the paints. Poly (vinyl acetate) was used as the binder while distilled water served as the solvent. The Eziulo clay which consisted mostly of silica (63.30\%), alumina (19.40\%), and iron (III) oxide $(2.10 \%)$ had the following properties: $\mathrm{pH}$ (6.67), specific gravity (2.47) and oil absorption ( $34.30 \mathrm{~g} / 100 \mathrm{~g}$ clay). The colour and solubility of the clay in dilute hydrochloric acid, acetic acid, sodium chloride solution, methanol and distilled water were generally unaffected either in the cold or when heated expect for the slight solubility observed in methanol. The clay formulated paint samples exhibited higher viscosity $(7.0-7.80$ poise $)$ than the paint sample without Eziulo clay (6.60 poise). Conversely, the $\mathrm{pH}$ and specific gravity of the paint sample without Eziulo clay were higher than those of paint sample containing the clay. The surface and hard dry times of the formulated paint samples were greater than that of the paint sample without Eziulo clay. The determined surface dry times were within the range, 16 - $18 \mathrm{~min}$, irrespective of clay content and particle size. The hard dry times of the formulated paint samples were found to reverse with increases in clay content. The paint dry film flexibility was unaffected by the incorporation of clay, irrespective of the amount and clay particle size. The emulsion paint dry films exhibited decreases in film adhesion to substrates with increases in clay content, and increases in film adhesion with increases in clay particle size. The paint dry films did not exhibit any chalking tendency, were resistant to fungal attack, and passed the water drop test. The present study has demonstrated the utility of Eziulo clay in emulsion paint formulations which should justify its use in the surface coatings industry.
\end{abstract}




\section{Keywords}

Extender, Emulsion Paint, Eziulo Clay, Drying Properties, Titanium Dioxide, Clay Particle Size, Characterization

\section{Introduction}

Extenders are inert substances which do not impact opacity to paints but are incorporated into paints for a variety of reasons [1]. They modify various coating properties such as viscosity, adhesion, hardness, gloss, abrasion resistance, flow characteristics, settling tendencies, etc. [2]. The selection and proper blending of suitable extenders help to optimize several engineering properties and the aesthetics of coatings.

Most of the extender pigments used in coatings such as titanium dioxide $\left(\mathrm{TiO}_{2}\right)$ are of mineral origin and require long processing, including grinding, levigation, chemical treatment, etc, from the ore to the final stage, resulting in significant loss of materials [3]. Similarly, these processed extenders are expensive, and are not available in abundance, and this has led to increases in the cost of resultant coatings products [4]. $\mathrm{TiO}_{2}$, a prime pigment which is used extensively in the paint industry is chemically active and contributes not only to the high cost of paints, but also, increases the rate of degradation of paint surfaces [5]. Efforts are being made to find economically and technically viable extenders for use in coatings, and thus, bring down the cost of coatings products to acceptable limits.

Clay, which is one of the natural resources that are abundant on earth, is being investigated for possible use as extenders in coatings. The use of calcined clay as part replacement of $\mathrm{TiO}_{2}$ in latex paint formulations has been reported [6]. It was found that the calcined clay replaced up to $20 \% \mathrm{TiO}_{2}$ in paint formulations without having adverse effects on coating properties. Similarly, the use of Okposi and Amankwo Afikpo clays in alkyd paint formulations was reported by Igwe and Ezeamaku [7]. The formulated paints which contained 13.1 to $36.0 \mathrm{wt} \%$ of the clays exhibited good paint properties as the commercial whiting formulated paint samples.

Raheem and Olowu [8] produced emulsion paints using two types of clays: white tinged with purple and smooth clay, and grey brown and coarse clay. Paints produced were compared to conventional chemical pigmented paint which served as a control. It was found that the clays could serve as partial replacement for chemical pigments in paint production. An indigenous China clay (kaolin) from Mbano, Nigeria was used as an extender in alkyd paint production by Odozi et al. [9]. The performance characteristics of the clay in alkyd paints were comparable, and even, marginally better than the imported commercial China clay.

The performance of Obowo, and Ihitte-Uboma clays- $\mathrm{TiO}_{2}$ core-shell extender pigments in alkyd paint formulations was investigated by Ewulonu et al. [10]. 
Results showed that the core-shell extender pigment formulated paints exhibited better dust-free, talc-free, and through-dry times as compared to titanium dioxide formulated paint samples, and equally, had low specific gravity (1.30 - 1.38). Similarly, Chukwujike et al. [11] formulated alkyd paints having improved paint properties using indigenous Nsu clay calcined at $850^{\circ} \mathrm{C}$. $\mathrm{TiO}_{2}$ was used as the prime pigment in this study.

The present paper reports the characterization and utilization of Eziulo clay obtained from Ishielu Local Government Area, Ebonyi state, Nigeria in the preparation of emulsion paints. Emulsion paints based on commercial whiting were also prepared and these served as reference paint samples.

\section{Materials and Methods}

\subsection{Materials}

The poly (vinyl acetate) used in this study was obtained from TK Integrated Services Limited, Ojota, Nigeria while commercial whiting, titanium dioxide, linseed oil and stearic acid were purchased from a chemical store at Onitsha, Nigeria.

The Eziulo clay used as an extender in this study was hand dug from the clay deposit at Ishielu Local Government Area, Ebonyi State, Nigeria. The clay which was first crushed and calcined at $850^{\circ} \mathrm{C}$ was sieved to the following particle sizes, $0.075,0.100$, and $0.150 \mathrm{~mm}$.

\subsection{Determinations on Clay Sample}

The following tests were carried out on the clay sample using standard methods: pH (ASTM D 1208-89), specific gravity (ASTM D 153-84), oil absorption (ASTM D 281-12), and chemical composition (ASTM D 5381-93).

\subsection{Preparation of Emulsion Paint Samples}

A series of emulsion paint samples were prepared using Eziulo clay, commercial whiting, and titanium dioxide. The commercial whiting was used as a reference extender. A typical formulation used in the preparations is shown in Table 1.

\subsection{Characterization of Prepared Paint Samples}

The prepared emulsion paints were characterized in terms of the following paint properties using standard methods: $\mathrm{pH}$ (ASTM D 1208-90), viscosity (ASTM D 1200-10), and specific gravity (ASTM D 1475-13). The dry times (surface, and hard dry times), paint flexibility, adhesion to substrate, water drop test, resistance to fungal attack and chalking test were conducted in accordance to Nigerian industrial standards NIS [12].

\section{Results and Discussion}

\subsection{Composition Analysis of Eziulo Clay}

The results of chemical composition analysis of Eziulo clay determined using 
energy dispersive X-ray fluorescence spectrometer (EDXRF) are presented in Table 2.

The result shows the appreciable presence of silica $\left(\mathrm{SiO}_{2}\right)$ and alumina $\left(\mathrm{Al}_{2} \mathrm{O}_{3}\right)$ in the clay, followed by titanium dioxide $\left(\mathrm{TiO}_{2}\right)$ and iron (III) oxide $\left(\mathrm{Fe}_{2} \mathrm{O}_{3}\right)$, with the other constituents present in smaller proportions. From Table 2, it is evident that Eziulo clay contains less than $65 \%$ silicon as recommended by World Health Organization, (WHO) [13] for clays to be used for paint production. Paints containing more than $65 \%$ silicon can cause fibrosis, silicosis, and lung cancer [13].

Table 1. Formulations for emulsion paint samples.

\begin{tabular}{|c|c|c|c|c|c|c|c|c|c|c|c|c|c|c|c|}
\hline \multirow{4}{*}{$\begin{array}{l}\text { Ingredients } \\
\qquad \mathrm{TiO}_{2}\end{array}$} & \multicolumn{10}{|c|}{ Formulations (g) } & & & & & \\
\hline & \multicolumn{5}{|c|}{$0.075 \mathrm{~mm}$} & \multicolumn{5}{|c|}{$0.100 \mathrm{~mm}$} & \multicolumn{5}{|c|}{$0.150 \mathrm{~mm}$} \\
\hline & A0F0 & A1F1 & A1F2 & A1F3 & AF4 & A0F0 & A2F1 & A2F2 & A2F3 & A2F4 & A0F0 & A3F1 & A3F2 & A3F3 & A3F4 \\
\hline & 12 & 11 & 10 & 8 & 6 & 12 & 11 & 10 & 8 & 6 & 12 & 11 & 10 & 8 & 6 \\
\hline Whiting & 26 & 25 & 24 & 22 & 20 & 26 & 25 & 24 & 22 & 20 & 26 & 25 & 24 & 22 & 20 \\
\hline Clay & 0 & 2 & 4 & 8 & 12 & 0 & 2 & 4 & 8 & 12 & 0 & 2 & 4 & 8 & 12 \\
\hline Binder & 7 & 7 & 7 & 7 & 7 & 7 & 7 & 7 & 7 & 7 & 7 & 7 & 7 & 7 & 7 \\
\hline Solvent & 100 & 100 & 100 & 100 & 100 & 100 & 100 & 100 & 100 & 100 & 100 & 100 & 100 & 100 & 100 \\
\hline Thickener & 6 & 6 & 6 & 6 & 6 & 6 & 6 & 6 & 6 & 6 & 6 & 6 & 6 & 6 & 6 \\
\hline Defoamer & 0.5 & 0.5 & 0.5 & 0.5 & 0.5 & 0.5 & 0.5 & 0.5 & 0.5 & 0.5 & 0.5 & 0.5 & 0.5 & 0.5 & 0.5 \\
\hline Preservative & 1.0 & 1.0 & 1.0 & 1.0 & 1.0 & 1.0 & 1.0 & 1.0 & 1.0 & 1.0 & 1.0 & 1.0 & 1.0 & 1.0 & 1.0 \\
\hline $\mathrm{pH}$ corrector & 0.3 & 0.3 & 0.3 & 0.3 & 0.3 & 0.3 & 0.3 & 0.3 & 0.3 & 0.3 & 0.3 & 0.3 & 0.3 & 0.3 & 0.3 \\
\hline
\end{tabular}

Note: A0F0 = Formulation without Eziulo clay; A1Fi $=$ Formulation with Eziulo clay of particle size, $0.075 \mathrm{~mm}$; A2Fi $=$ Formulation with Eziulo clay of particle size, $0.100 \mathrm{~mm}$; A3Fi= Formulation with Eziulo clay of particle size, $0.150 \mathrm{~mm}$; where i = 1, 2, 3, 4 .

Table 2. Composition of Eziulo clay.

\begin{tabular}{cc}
\hline Constituents & Composition, wt \% \\
$\mathrm{SiO}_{2}$ & 63.30 \\
$\mathrm{Al}_{2} \mathrm{O}_{3}$ & 19.40 \\
$\mathrm{TiO}_{2}$ & 1.64 \\
$\mathrm{Fe}_{2} \mathrm{O}_{3}$ & 2.10 \\
$\mathrm{MgO}$ & 0.08 \\
$\mathrm{CaO}$ & 0.17 \\
$\mathrm{Na}_{2} \mathrm{O}$ & 0.63 \\
$\mathrm{~K}_{2} \mathrm{O}$ & 0.36 \\
$\mathrm{~V}_{2} \mathrm{O}_{5}$ & 0.08 \\
$\mathrm{MnO}$ & 0.08 \\
$\mathrm{Bi}_{2} \mathrm{O}_{3}$ & 0.10 \\
$\mathrm{C}_{2} \mathrm{O}_{3}$ & 0.07 \\
$\mathrm{~L}_{3} \mathrm{O} . \mathrm{I}$. & 11.23 \\
\hline
\end{tabular}




\subsection{Determinations on Eziulo Clay}

\subsubsection{Specific Gravity}

The specific gravity of Eziulo clay was determined to be 2.47, a value which is less than that of commercial whiting (2.70) [7], and many other conventionally used extenders [14] [15]. The above result gives the clay the advantage of being able to be used in high proportions without having adverse increase in the bulk density of the formulations [2].

\subsection{2. $\mathrm{pH}$}

The $\mathrm{pH}$ of Eziulo clay was determined to be 6.67 , a value which shows that the clay is slightly acidic. The $\mathrm{pH}$ of some extenders are: talc (9 - 9.5), fly ash (8.15) [16], Okigwe-Mbano clay (6.0) [9], Amankwo-Afikpo clay (7.46) [7], and an indigenous waste clay (7.88) [17].

\subsubsection{Oil Absorption}

Eziulo clay has an oil absorption value of $34.30 \mathrm{~g} / 100 \mathrm{~g}$ clay. The oil absorption of an extender gives an idea of the amount of binder required in paint formulation. Less oil absorption indicates less resin needed in paint formulation without compromising other coating properties. The oil absorption of some extenders are: fly ash (19.0), China clay (30 - 60) [3], barites (10 - 14), gypsum (20 - 24) [14], mica (50 - 70), talc (25 - 35) [16], and Okigwe-Mbano clay (60) [9]. The level of oil absorption recorded for Eziulo clay indicates that more of the clay can be incorporated into paints without compromising other paint properties.

\subsubsection{Chemical Resistance Tests}

Dilute hydrochloric acid, methanol, acetic acid, sodium chloride solution, and distilled water had no effect on the colour of Eziulo clay either in the cold or when heated. Similarly, the clay did not dissolve in the chemical media studied either in the cold or when heated except for the slight solubility of the clay recorded in methanol when heated. Thus, Eziulo clay is expected to be stable in the surrounding environment of use devoid of the presence of methanol as the above results indicate. The observed stability of the clay is attributed to the high $\mathrm{SiO}_{2}$ (63.30\%) and $\mathrm{Al}_{2} \mathrm{O}_{3}$ (19.40\%) content of the clay. It is interesting to note that $\mathrm{SiO}_{2}$ has a melting point of $1713^{\circ} \mathrm{C}$ while $\mathrm{Al}_{2} \mathrm{O}_{3}$ has a melting point of 2054 ${ }^{\circ} \mathrm{C}$ [18] [19] [20] [21]. These two compounds, $\mathrm{SiO}_{2}$ and $\mathrm{Al}_{2} \mathrm{O}_{3}$ are insoluble in water and mineral acids [22]. The extender talc has been reported to be slightly soluble in dilute hydrochloric acid while commercial whiting is soluble in acetic acid [16]. Generally, if an extender dissolves in its solvent as the paint dries, the solvent comes to the surface and evaporates, thereby leaving crystals of the extender on the paint surface in the form of fine powder.

\subsection{The Effects of Clay Content and Particle Size on Properties of Emulsion Paint Samples}

The effects of Eziulo clay content and particle size on the properties of the wet paint, and paint dry films of emulsion paint samples were determined using 
standard methods.

\subsubsection{Viscosity of Paint Samples}

Data obtained on the viscosity of the prepared emulsion paints are illustrated graphically in Figure 1.

The figure shows a gradual increase in the viscosity of the paint samples with increases in clay content for any clay particle size considered. Similarly, at any clay content considered the viscosity of the paint samples generally decrease with increases in clay particle size. The latter observation is attributed to the fact that the smaller the particle size of an extender, the greater will be its parking efficiency and consequently, the greater the viscosity of its paint [23]. Generally, the formulated emulsion paint samples exhibited higher paint viscosity than the sample without clay. The viscosity of the formulated paint samples obtained in this study conformed to Nigerian Industrial Standards, NIS [12] requirement that the minimum viscosity for emulsion paints shall be 6.0 poise.

\subsubsection{Specific Gravity}

Figure 2 illustrates the data obtained for the specific gravity of the formulated paint samples at different clay contents and particle sizes. The figure shows that at any clay content considered, the specific gravity of the paints decreased with increases in clay particle size. Similarly, the specific gravity of the paints decreased with increases in clay particle size at any clay content considered.

The formulated emulsion paints exhibited low specific gravity when compared to the paint sample without the Eziulo clay (specific gravity, 2.78). The high specific gravity of $\mathrm{TiO}_{2}$ formulated emulsion paint is to be expected since $\mathrm{TiO}_{2}$ used in this study, a product of Sigma Aldrich, has a specific gravity of 4.26.

\subsection{3. $\mathrm{pH}$}

The $\mathrm{pH}$ of the formulated paint samples illustrated graphically in Figure 3

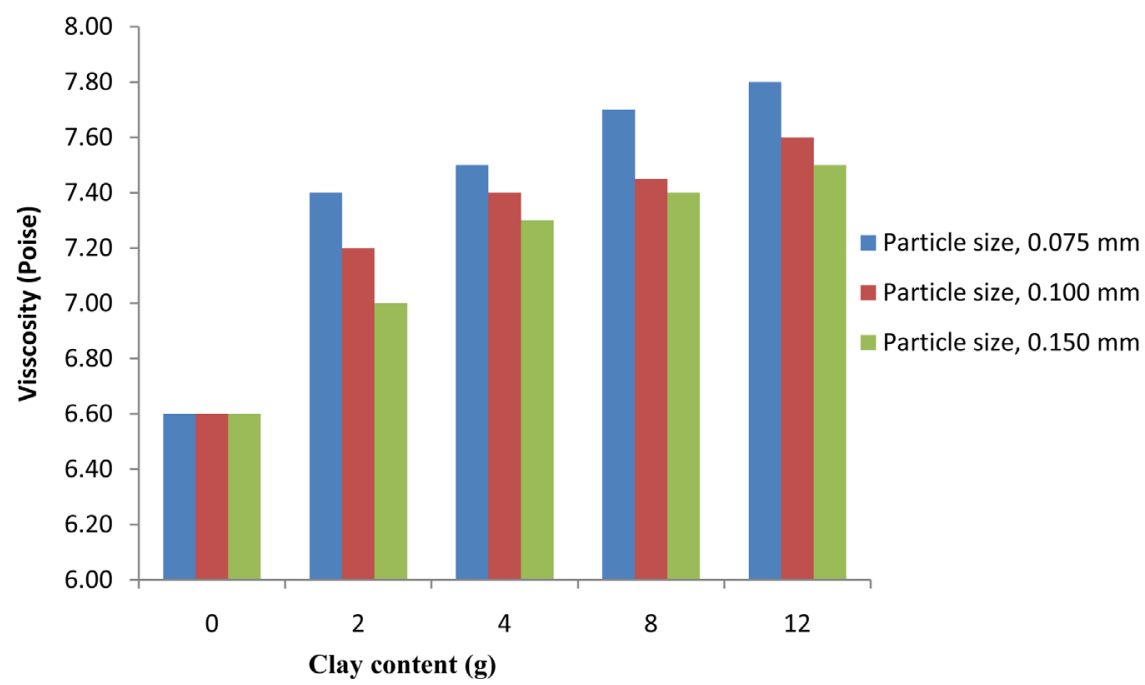

Figure 1. Effect of clay content and particle size on the viscosity of formulated emulsion paints. 


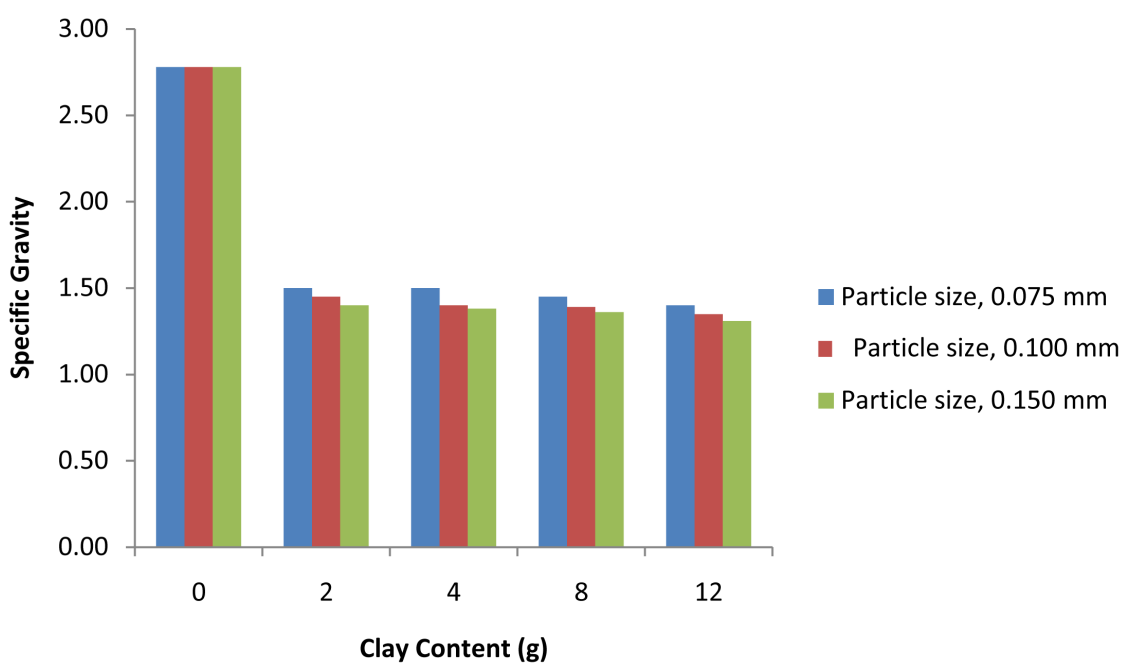

Figure 2. Effect of clay content and particle size on the specific gravity of formulated emulsion paints.

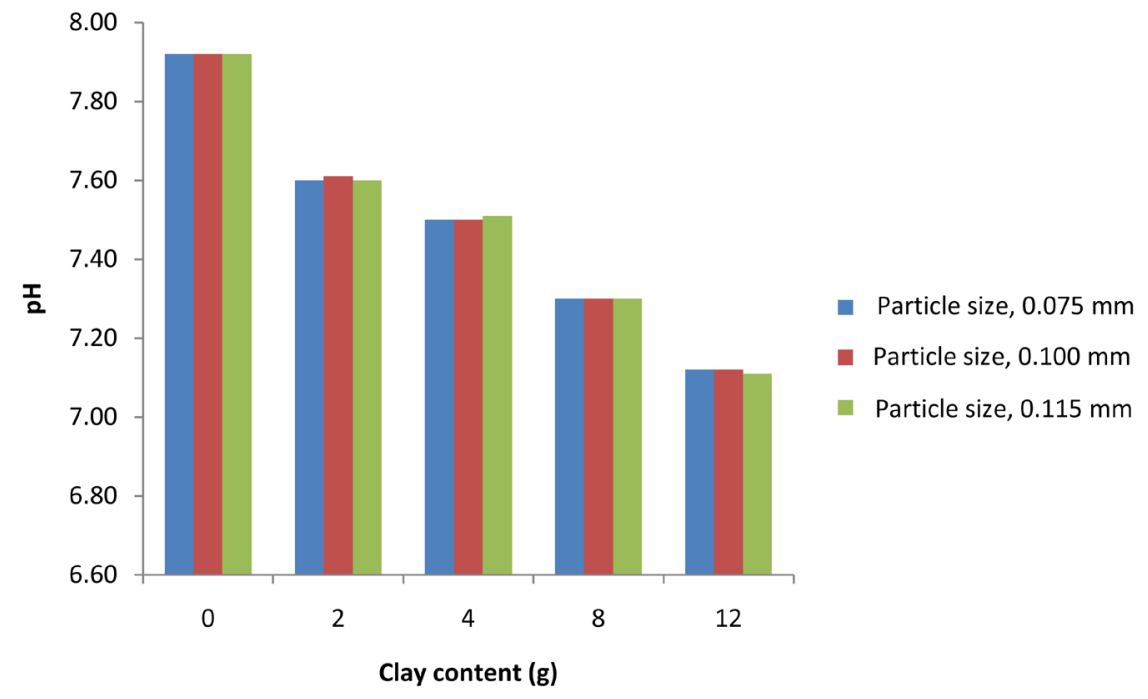

Figure 3. Effect of clay content and particle size on the $\mathrm{pH}$ of formulated emulsion paints.

shows decreases in $\mathrm{pH}$ of paint samples with increases in clay content at any clay particle size investigated. However, clay particle size has no appreciable effect on the $\mathrm{pH}$ of the paint samples. The formulated paint samples had $\mathrm{pH}$ values in the range, 7.0 - 8.0. According to Nigerian industrial standards, NIS [12], emulsion paint shall have a $\mathrm{pH}$ in the range of 7.0 - 9.0; an indication that all the formulated emulsion paint samples passed the NIS requirement for emulsion paints.

\subsubsection{Paint Dry Times}

The data on the dry times (surface, and hard dry times) of the formulated paint samples are illustrated graphically in Figure 4 and Figure 5. Figure 4 shows that the surface dry times of the formulated paint samples were greater than that of paint sample without the Eziulo clay.

Generally, the surface dry times of the emulsion paint samples were within the 


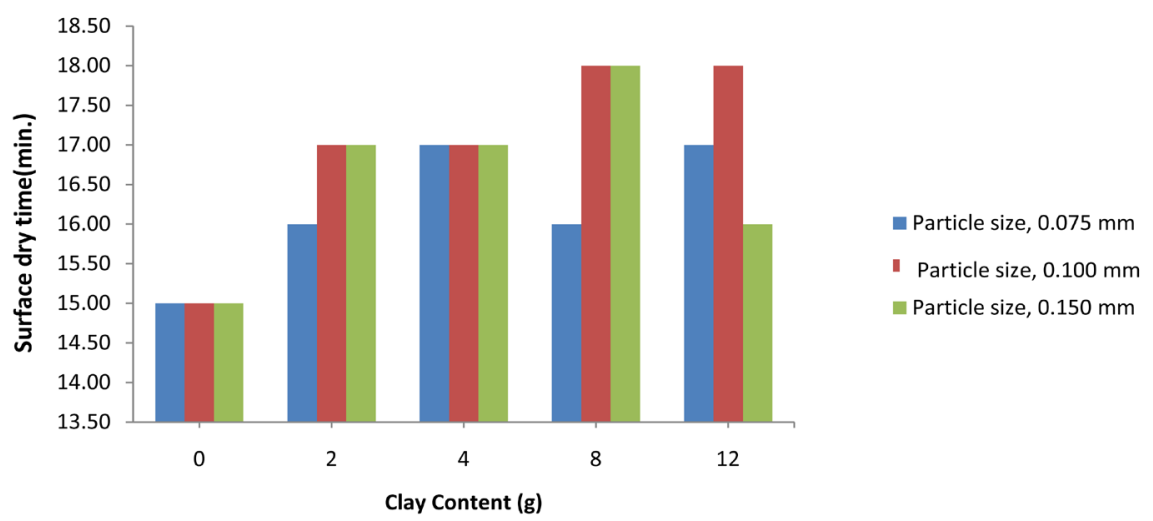

Figure 4. Effect of clay content and particle size on the surface dry times of formulated emulsion paints.

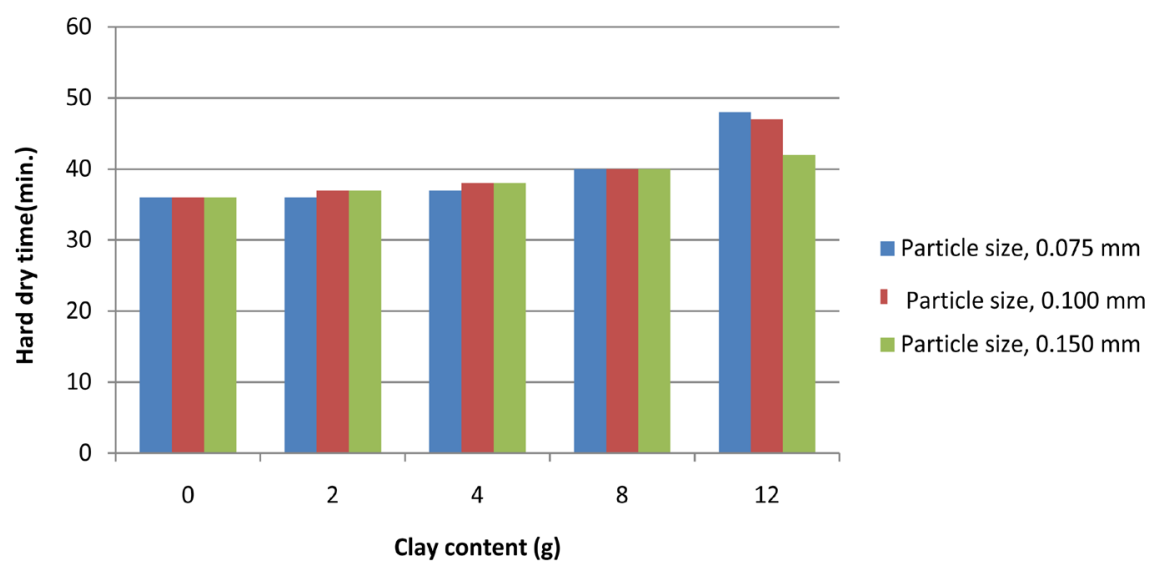

Figure 5. The effect of clay content and particle size on hard dry times of formulated emulsion paints.

range, 16 - $18 \mathrm{~min}$, irrespective of the clay content and particle size. Similarly, the formulated emulsion paint samples exhibited higher hard dry times than the paint sample without Eziulo clay. From Figure 5, it is evident that at any clay particle size considered, the hard dry times of the formulated emulsion paint samples increased with increases in clay content. The formulated paint samples satisfied the NIS [12] requirements for the surface and had dry times of emulsion paints which shall be 20 min maximum for surface dry time, and $120 \mathrm{~min}$ maximum for hard dry time.

\subsubsection{Flexibility of Paint Dry Films}

The flexibility tests performed on the dry films of the emulsion paints showed that the flexibility of the paint dry films were unaffected by the incorporation of Eziulo clay; irrespective of the amount and particle size of the clay. The paint dry films passed the NIS [12] flexibility test as there was no cracking, peeling or delamination on any of the paint dry films tested.

\subsubsection{Adhesion to Substrate of Paint Dry Films}

The adhesion properties of the formulated emulsion paint dry films to glass panels are illustrated in Figure 6. The figure shows that all the paint dry films 


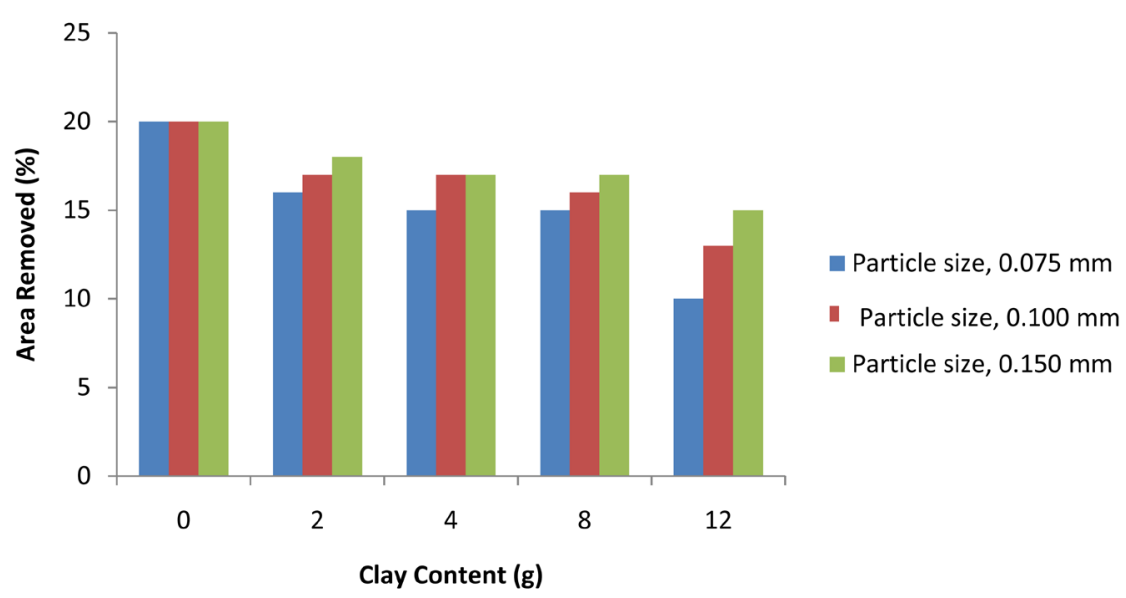

Figure 6. Effect of clay content and particle size on adhesion of formulated emulsion paints to substrates.

passed the adhesion test because the removal of paint films in each case was less than $50 \%$ of the square lines of the coat [12]. There was a progressive increase in the adhesion of the paint films with increases in clay particle size for all the clay contents investigated. However, the adhesion of the paint films to glass substrates generally decreased with increases in clay content at any clay particle size considered.

\subsubsection{Water Drop Test}

The water drop tests performed on the paint samples showed that the paint samples passed the water drop test as there was no swelling, blistering, and cracking of the paint films [12]. It is important to note that water in one way or another is the common enemy to most materials of construction. With some exceptions, protective coatings are designed to control the action of water.

\subsubsection{Resistance to Fungal Attack}

The paint dry films exposed to the outside of the laboratory for 3 months were observed to be resistant to fungal attack as there was no growth of fungi from any of them, an indication of good performance of Eziulo clay in coatings [24].

\subsubsection{Chalking Test}

None of the formulated emulsion paint samples chalked, just like the paint sample formulated without Eziulo clay. A good paint should not chalk.

\section{Conclusions}

Eziulo clay obtained from Ishielu Local Government Area of Ebonyi State; Nigeria has been used successfully to formulate emulsion paints with improved properties.

The specific gravity, $\mathrm{pH}$ and oil absorption of the clay were determined to be $2.46,6.67,34.30 \mathrm{~g} / \mathrm{g}$ clay respectively. The clay consisted mostly of silica (63.30\%), alumina (19.40\%), and iron (III) oxide (2.10\%). The colour of Eziulo clay was unaffected in the following media: dilute hydrochloric acid, acetic acid, 
distilled water, and sodium chloride solution. Similarly, the clay did not dissolve in the chemical media tested except for the slight solubility observed in methanol.

The specific gravity and $\mathrm{pH}$ of the formulated emulsion paint sample without Eziulo clay were higher than those containing the clay. These properties generally decrease with increases in clay content and particle size. However, the viscosity of Eziulo clay formulated paint samples was higher than that of the paint without Eziulo clay.

The formulated emulsion paint samples exhibited good surface and hard dry times. Generally, the surface and hard dry times of the paint without Eziulo clay were slightly lower than those of the paints containing Eziulo clay. The clay formulated paints exhibited better adhesion to substrates than the paint without the clay; the adhesion increased with increases in clay content, and decreased with decreases in clay particle size.

The paint dry films exhibited good flexibility as there was no cracking, peeling and delamination on any of the surfaces painted with the formulated paints. Similarly, the paint samples did not chalk, passed the water drop test, and were resistant to fungal attack, all attesting to good paint qualities obtainable with Eziulo clay.

\section{References}

[1] Talbert, R. (2007) Paint Technology Handbook. Grand Rapids, Michigan. https://doi.org/10.1201/9781420017786

[2] Woodridge, R. (1991) Principles of Paint Formulation. Chapman and Hall, New York, 51-52. https://doi.org/10.1007/978-1-4615-3674-1

[3] Morgans, W.M. (1990) Outlines of Paint Technology. Edward Arnold, London.

[4] Prem, K.N., Sathyanarayana, M.N., Bala, K.R.S., Shirsalkar, M.N. and Rado, P. (1988) An Introduction to the Technology of Pottery. Pergamon Press, Oxford.

[5] PCI (Paint and Coating Industry) Magazine (2005) A Comprehensive Understanding of $\mathrm{TiO}_{2}$ Durability.

http://www.pcimag.com/articles/82840-a-comprehensive-understanding-of- $\mathrm{TiO}_{2}$-pi gment-durability

[6] Naranyan, R. and Raju, K.V.S.N. (1999) The Use of Calcined Clay in Organic Coatings and Polymers. Indian Institute of Chemical Technology, Hyderabab.

[7] Igwe, I.O. and Ezeamaku, L.U. (2010) The Use of Local Clays in Alkyd Paint Formulations. Malysian Polymer Journal, 5, 81-94.

[8] Raheem, A. and Olowu, O.A. (2013) Production of Household Paint Using Clay Minerals. International Journal of Engineering Research and Applications, 3, 85-93.

[9] Odozi, T.O., Dore, R. and Onu, C.O. (1986) Paint Extenders Based Upon an Indigenous Clay. Journal of Nigerian Society of Chemical Engineering, 5, 34-40.

[10] Ewulonu, C.M., Igwe, I.O. and Onyeagoro, G.N. (2016) Performance of Local Clay-Titanuim Dioxide Core-Shell Extender Pigments in Alkyd Paints. Advances in Nanoparticles, 5, 90-102. https://doi.org/10.4236/anp.2016.51011

[11] Chukwujike, I.C., Igwe, I.O. and Onyeagoro, G.N. (2016) Performance Evaluation of Local Clay-Extender Pigment on Alkyd Paint Formulations. International Journal of Modern Research in Engineering and Technology, 1, 30-41. 
[12] NIS (Nigerian Industrial Standards) (1989) Standard for Paints and Vanishes Part 3. Nigerian Industrial Standard, Lagos.

[13] WHO (World Health Organization) (2005) Bentonite, Kaolin and Selected Clay Minerals. Environmental Health Criteria 231.

[14] Wosniak, M. (1988) Overview of Extenders: Basic Properties, Types, and Processing. Federation Societies for Coatings Technology, Philadelphia.

[15] Ciullo, P.A. and Anderson, J. (2002) Industrial Talc. Journal of Coatings Technolo$g y$, 5, 15-19. https://doi.org/10.1007/BF02697955

[16] Tiwari, S.N. and Saxena, M. (1999) Use of Fly Ash in High Performance Industrial Coatings. British Corrosion Journal, 34, 184-191. https://doi.org/10.1179/000705999101500824

[17] Anyiam, K.C. and Igwe, I.O. (2012) Studies on an Industrial Waste Clay in Alkyd Paint Formulations. International Journal of Academic Research, 4, 48-53.

[18] Haynes, M.N. (2011) Handbook of Chemistry and Physics. 92nd Edition, CRC Press, Florida.

[19] Scherzer, J. (1978) Dealuminated Faujasite-Type Structure with $\mathrm{SiO}_{2} / \mathrm{Al}_{2} \mathrm{O}_{3}$ Ratio's over 100. Journal of Catatylsis, 54, 285-288. https://doi.org/10.1016/0021-9517(78)90051-9

[20] Lager, G.A., Jorgensen, J.D. and Rotella, F.J. (1982) Crystal Structure and Thermal Expansion of a Quartz $\mathrm{SiO}_{2}$ at Low Temperature. Journal of Applied Physics, 53, 6751.

[21] Lewis, R.J. (2007) Hawley's Condensed Chemical Dictionary. 15th Edition, John Wiley and Sons Incorporated, New York, 49. https://doi.org/10.1002/9780470114735

[22] Laine, R.M., Blohowiak, K.Y., Robinson, T.R., Hoppe, M.L., Nardi, P., Kampf, J. and Uhm, J. (1991) Synthesis of Pentacoordinate Silicon Complexes from $\mathrm{SiO}_{2}$. Journal of Materials Science and Engineering, 353, 642-644. https://doi.org/10.1038/353642a0

[23] Bierwagen, G.P. and Sanders, T.E (1974) Studies of the Effect of Particle Size Distribution on the Pocking Efficiency of Particle Size. Science Direct, 10, 111-119.

[24] Boxall, J. and van Fraunhofer, J.A. (1977) Concise Paint Technology. Chemical Publishing, New York.

Scientific Research Publishing

Submit or recommend next manuscript to SCIRP and we will provide best service for you:

Accepting pre-submission inquiries through Email, Facebook, LinkedIn, Twitter, etc.

A wide selection of journals (inclusive of 9 subjects, more than 200 journals)

Providing 24-hour high-quality service

User-friendly online submission system

Fair and swift peer-review system

Efficient typesetting and proofreading procedure

Display of the result of downloads and visits, as well as the number of cited articles

Maximum dissemination of your research work

Submit your manuscript at: http://papersubmission.scirp.org/

Or contact jmmce@scirp.org 